19 Revue d'histoire du XIXe siècle

Société d'histoire de la révolution de 1848 et des

révolutions du XIXe siècle

$11 \mid 1995$

L'exil

\title{
Des débuts de la Monarchie de Juillet à la fin du Second Empire : intellectuels et hommes politiques français en exil en Belgique
}

\section{Francis Sartorius}

\section{OpenEdition}

\section{Journals}

Electronic version

URL: http://journals.openedition.org/rh19/81

DOI: $10.4000 /$ rh19.81

ISSN: $1777-5329$

\section{Publisher}

La Société de 1848

Printed version

Date of publication: 1 June 1995

ISSN: 1265-1354

\section{Electronic reference}

Francis Sartorius, «Des débuts de la Monarchie de Juillet à la fin du Second Empire : intellectuels et hommes politiques français en exil en Belgique », Revue d'histoire du XIXe siècle [Online], 11 | 1995,

Online since 09 September 2008, connection on 19 April 2019. URL : http://journals.openedition.org/ rh19/81; DOI : 10.4000/rh19.81

This text was automatically generated on 19 April 2019

Tous droits réservés 


\title{
Des débuts de la Monarchie de Juillet à la fin du Second Empire : intellectuels et hommes politiques français en exil en Belgique
}

\author{
Francis Sartorius
}

\section{ABSTRACTS}

From the beginnings of the July Monarchy to the end of the Second Empire: French intellectuals and politicians in exile in Belgium Both the common language and the geographical proximity made Belgium the ideal land of exile for the French. Belgium was a haven for them, although life there was not without constraints - the Belgian government wanted to preserve its independence, but was anxious not to displease its neighbour. In this article, Francis Sartorius presents the forgotten figures of opponents of the 1830s and 1840s. Some of these people, such as Mathé and Labrousse endured exile again in 1851. The coup d'État that took place at that time changed the scale of banishment. From a handful of activists who found a refuge in Belgium every time their party failed, numbers rose to nearly six thousand refugees. The Belgian government then applied a strict policy: it refused those who were considered to be undesirable, it imposed eligibility conditions related to income, it placed restrictions on where the exiles could live of residence. The figure subsequently decreased, leaving only a handful of indomitable Belgian exiles left, waging a difficult and often muted struggle. However, numbers were boosted at the end of the Empire by the arrival of young, far left, internationalist activists and of the journalist Rochefort. 
La communauté de langue et la proximité géographique ont fait de la Belgique la terre d'exil par excellence des Français. La Belgique est un havre de paix mais non sans contraintes, le gouvernement belge souhaitant tout en présevant son indépendance ne pas mécontenter son voisin. Francis Sartorius présente la figure oubliée d'opposants des années 1830 et 1840, certains d'entre eux comme Mathé ou Labrousse connaîtront à nouveau l'exil en 1851. Le coup d'État change l'échelle de la proscription. On passe d'une poignée d'activistes qui trouvent refuge en Belgique à chaque échec de leur parti à une arrivée massive de prés de 6000 républicain. Le gouvernement belge applique alors une politique plus sévère: refoulant les indésirables, imposant des conditions de revenus, dictant les lieux de résidence. Le nombre décroit donc et la proscription belge réduite à une poignée d'irréductibles mène un combat difficile et souvent feutré. Elle est malgré tout revivifiée à la fin de l'Empire par l'arrivée de jeunes militants d'extreme-gauche internationalistes et par celle du journaliste Rochefort.

INDEX

Mots-clés: Exil 